\title{
Impact of Risk-Related Disclosure on the Risk-Taking Behavior of Commercial Banks in Pakistan
}

\author{
Mamoona Naz \\ Huma Ayub ${ }^{2}$
}

\begin{abstract}
Information asymmetry leads to moral hazard in commercial banks, as evidenced in the 2008 crisis. This study aims at analyzing the implications of risk disclosure practices of commercial banks on their risk-taking behavior in Pakistan. It also attempts at assessing the level of compliance for commercial banks with the specifications of Basel accord II under Pillar 3. For measuring disclosure level, a risk disclosure index is devised. The dependent variable i.e. risk-taking behavior is operationalized through portfolio risk. The analysis employed panel data techniques of Ordinary Least Squares (OLS). The relationship of risk disclosure index with risk-taking behavior, as expected, is found to be significantly negative; in line with information asymmetry and moral hazard hypotheses. These discoveries are consistent with the essence of market discipline that greater disclosure enables stockholders to more closely monitor and scrutinize, resulting in contrived and sensible risk taking. The results of the study provide evidence on the current state of market discipline and the vital part it plays in the risk-taking behavior of Pakistani commercial bank. This study is also significant for the regulators, and financial managers, that need adequate information for making informed decisions. As the results empirically confirm the issue of non-disclosures with an intent to take higher risks, in commercial banks of Pakistan. In the light of this study, the policy makers can strengthen regulations that govern risk disclosure practices, in order to uphold market discipline, realizing the ultimate objective of State Bank of Pakistan and Basel Committee for Banking Supervision.
\end{abstract}

Keywords: Risk Disclosures, Basel Accord II, Risk Taking Behavior, Disclosure Index, Moral Hazard, Market Discipline

\section{INTRODUCTION}

Bank supervisors have embraced the concept of market discipline as a supportive tool to their supervisory and regulatory measures; for monitoring risk in individual banks and in the banking system as whole (Benink \& Wihlborg, 2002). Adequate risk disclosures are essential for this concept to work. The financial crisis of 2007 and its worldwide consequences also raised questions about the awareness of risks financial intermediaries remain exposed to, and the techniques and procedures they have in place to manage such risks (Krugman, 2009).

In light of this Basel Committee for Banking Supervision (BCBS) devised risk disclosure requirements in Basel-II under Pillar-3 of market discipline to ensures adequate risk disclosures on the part of commercial banks, assisting shareholders and other stakeholders in decision-making (Hakenes \& Schnabel, 2011). These requirements are imposed to deter agency conflict and information asymmetry ultimately eliminating moral hazard incentives (Baumann \& Nier, 2004; Benink \& Wihlborg, 2002; Ghosh \& Das, 2005; Jeitschko \& Jeung, 2005). For evaluation of the disclosure levels, the literature demonstrates the use of disclosure

1 - Student, Department of Business Administration, Fatima Jinnah Women University, Rawalpindi, Pakistan. mamoona08@gmail.com 2 - Assistant Professor, Department of Business Administration, Fatima Jinnah Women University, Rawalpindi, Pakistan.

\begin{tabular}{llll}
\hline JISR-MSSE & Volume 15 & Number 2 & July-Dec 2017 \\
\hline
\end{tabular}


indices; for instance: Baumann and Nier (2004), Nier (2005), Nier and Baumann (2006), Urquiza et al. (2010). Such tools can provide assistance to regulators, bankers and policy makers in upholding market discipline in any economy.

To determine the extent to which regulatory disclosure requirements are being met and therefore, successful in evading unwarranted risk-taking; it is essential to analyze the strength of association between risk-related disclosures and risk-taking behavior of banks. Such investigation is required, now more than ever, for Pakistani banking sector that remained relatively less affected in the 2007 crisis. However, due to its rapidly modernizing risk-trading markets, is also becoming exposed to the system risks inherent in financial intermediation (Masood \& Fry, 2012).

This study is significant for the regulatory bodies, banks and other stakeholders, as it sets a precedent with context to a developing country in general, and Pakistan in particular, on the matter. The role market discipline can play in evading financial crisis has come out ever stronger from this endeavor. The results of the study provide evidence on the current state of market discipline and the vital part it plays in the risk-taking behavior of Pakistani commercial bank. The policy makers at State Bank of Pakistan (SBP) can benefit from these findings in strengthening regulations that govern risk disclosure practices, in order to uphold market discipline, fulfilling the ultimate objective of SBP and BCBS.

\section{Research Objectives}

The study aims are,

1. To analyze the impact of risk disclosure on the risk-taking behavior of Pakistani CBs.

2. To measure the compliance levels of CBs with Pillar-3 regulations.

And,

3. To explore the implications of risk disclosures on the risk-taking behavior of commercial banking sector of Pakistan.

\section{LITERATURE REVIEW}

As accounting discretion provides bankers with opportunities to take on excessive risk in the expectation of earning higher returns (Besancenot \& Vranceanu, 2011; Jeitschko \& Jeung, 2005; Milne, 2002; Scott, 2014). Such excessive risk may not be disclosed to the shareholders inducing agency conflict and information asymmetry (Healy \& Palepu, 2001; Jensen \& Meckling, 1979). Whereas, if voluntarily disclosed such information can assist in decision making (Lundholm \& Van Winkle, 2006). However voluntary risk disclosures are not appreciated (Greco, 2012; Guttentag \& Herring, 1986), as unnecessary disclosure can decrease market value, and cause bank runs among other problems (Östberg, 2006). Whereas non-disclosure can aid moral hazard (Jeitschko \& Jeung, 2005; Jensen \& Meckling, 1979; Krugman, 2009; Nier \& Baumann, 2006).

To curb such excessive risk-taking, regulations are designed to ensure risk disclosure. With sufficient risk-related information, inefficient risk-taking and inadequate capital backup; a bank exposes itself to market disciplining (Ghosh \& Das, 2005; González, 2005). A major regulatory step in this regard is Basel-II, wherein market discipline (Pillar-3) is recognized as a supportive tool to supervisory review and capital requirements regulations (Balin, 2008; Demirgüç-Kunt, Detragiache, \& Tressel, 2008; Vauhkonen, 2011).

126 July-Dec $2017 \quad$ Volume $15 \quad$ Number 2




\section{Basel-II Pillar-3: Market Discipline and Risk-Taking Behavior}

The risk disclosure requirements under Pillar-3 of Basel-II, are composed of fourteen different categories of disclosures regulations that collectively uphold market discipline, and accommodate scope of application of capital, risk-exposure and assessment. These requirements altogether influence the risk-taking behavior of the commercial banks due to market discipline (Basel Committee on Banking Supervision [BCBS], 2005). Among these categories, six are the most influential in this regard namely; capital structure, capital adequacy, credit risk modeling, operational risk, market risk internal-modeling and other risks (liquidity risk, legal risk and interest-rate risk) (Linsley \& Crumpton, 2006).

Capital requirements play a significant role in bank soundness and resilience. These requirements enforce adequacy of capital and design capital structures to provide for risks undertaken in financial intermediation. Capital structures influence risk-takings of banks, evidently causing financial disruptions (Duran \& Lozano-Vivas, 2015). Increase in leverage needs to be disclosed, as its non-disclosure can initiate moral hazard hypothesis (Benink \& Wihlborg, 2002; Rime, 2001).

Adequacy of capital is required for bank stability. If a bank runs low on capital against its risk profile, the regulatory authorities impose sanctions to protect depositors; leading to recapitalization needs (Duran \& Lozano-Vivas, 2015). Non-disclosure of capital inadequacy provides banks with incentives to take on more risk to earn higher profits and ultimately attract less costly funding from the market (Besancenot \& Vranceanu, 2011). The capital inadequacy hence becomes essential to be disclosed to aid market discipline and curtail excessive risk-takings by banks (Ghosh \& Das, 2005; Jacques \& Nigro, 1997; Rime, 2001).

Lending forms a major part of any bank's risk portfolio, being its core function. Commercial banks employ statistical procedures and models to constantly rate and rank their clients based on their riskiness. These models devise the credit risk information. being a component of total risk-exposures, increase in credit risk ultimately leads to increased risk-taking in the portfolio (Bessler \& Kurmann, 2014). Credit risk information hence becomes a part of risk-related disclosures. Disclosure on these models is required by the BCBS in the Pillar-3 of Basel-II for enforcement of market discipline and a stable banking environment (Linsley \& Shrives, 2005).

Basel-II defines operational risk as "... the risk of loss resulting from inadequate or failed internal processes, people and systems or from external events" (BCBS, 2005). An increase in operational risk points to the ineptitude of a bank; making inefficient investment choices (moral hazard). The transparency in this regard forces a bank to streamline its systems and processes to rid them of failures and risks, ultimately decreasing the inefficient risk-takings (Barakat \& Hussainey, 2013).

Market risk, like credit risk, involves models that banks devise and manage internally for the evaluation of their assets. Being a part of the portfolio risk, disclosure of information regarding these models is required in the Basel-II regulations (BCBS, 2005). Value-at-Risk disclosures are likely to equip market participants to fairly judge efficient banks from the inefficient ones and hence manage their stakes effectively. Information symmetry in this regard allows for disciplinary mechanism to sanction banks with ineffective management of market risk (Pérignon \& Smith, 2010; Savvides, 2012).

\begin{tabular}{llll}
\hline JISR-MSSE & Volume 15 & Number 2 & July-Dec 2017 \\
\hline
\end{tabular}


Other risks that compose risk disclosure regime include liquidity risk, legal risk and interest rate risk. Probability of a depositor run decreases with the increase in liquidity (Martinez Peria \& Schmukler, 2001). Therefore, banks need to keep adequate liquidity to cater for the withdrawal needs of the depositors, whilst invest surplus funds to yield returns. They need to invest funds at different maturities to provide for liquidity needs as well as earn significant margins. Decrease in liquidity represents inefficient management of funds and risk. Disclosure of such risk information can lower the probability of inefficient risk management and enforce adequate liquidity levels (Barako, Hancock, \& Izan, 2006).

Increase in the interest rate risk also occurs due to inefficient risk management. Increased disclosures as required by the Pillar- 3 on material interest rate positions, and all relevant re-pricing and maturity data can improve market discipline.

Increase in legal risks, that include but are not limited to any possible exposure to punitive damages, penalties, or fines resulting from supervisory actions, along with private settlements (BCBS, 2005), can escalate the overall risk levels of the banks requiring capital backup against them, and hence needs disclosure along with other risks.

Ultimately, market participants utilize information disclosed to penalize banks with excessive risks thus ensure stability (Agoraki, Delis, \& Pasiouras, 2011; Nier, 2005; Vauhkonen, 2011). Moreover, increased disclosure curbs banks' risk-taking for the fear of bank-runs, establishing stability and efficiency (Baumann \& Nier, 2004; Jeitschko \& Jeung, 2005; Linsley \& Shrives, 2005; Nier \& Baumann, 2006; Nier, 2005). On the basis of these arguments, it is hypothesized that;

\section{H1: Ceteris paribus, an increase in the Risk disclosures causes a decrease in the Risk-taking Behavior.}

\section{The Banking Sector of Pakistan ${ }^{1}$}

In 2013, the total assets of the commercial banking industry amounted to Rs. 10.5 trillion with an increase of 7.9 percent over 2012, portentous of expansion of banking sector in the last eight years. Big-five banks (HBL, NBP, UBL, MCB, ABL) share 60.2 percent of this pie (KPMG Taseer Hadi \& Co., 2013).

Bank advances increased 7.7 percent to Rs. 4.5 trillion in 2013 over Rs. 4.2 trillion in 2012. 12.4 percent of which went bad (Non-Performing Loans or NPLs) in 2013 against 13.6 percent in 2012 and 5.8 percent in 2006. Post 2007 facing massive levels of NPLs, banks became risk-averse and moved from risky advances with high-yields to low-yielding government securities. This strategic maneuver dropped the spread ratio from 56.9 percent in 2006 to 43.95 percent in 2013. The spreads further shrunk due to SBP's imposition of the minimum deposit rate (MDR) of 5 percent p.a. on the whole range of deposits w.e.f June 2008. The sector tactfully contrived the combined negative effect by reconfiguring deposits (Saleem, 2014). Such that, the share of fixed deposits plunged to 27 percent in 2013 against 35 percent in 2008 .

1 - Calculations provided in this section are based on the Financial Statement Analysis of Financial Sector (2008-13) issued by SBP.

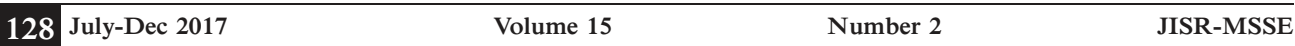


Contrarily current accounts' share improved from 27 percent in 2008 to 30 percent in 2013. This shift from fixed-to-current made investment in government securities more productive, while accommodating for the maturity profile. The total deposits encountered a decrease of 12.3 percent from 2012. The monetary ease of 500 basis points in 2012-13, further shrunk spreads by 12.27 percent in 2013 (Saleem, 2014).

Despite the effort of SBP to attract savings by increasing MDR, banks are not welcoming saving deposits. Besides abandoning lower-yields by diversified their earning methods, they are also keeping NPLs at bay by crowding out private-sector credit. However, SBP linked the rate at which $\mathrm{CBs}$ deposit their end-of-the-day cash with it on the overnight-basis known as repo-rate of 7 percent with MDR of $6.5 \mathrm{w}$-e-f October 1, 2013. This was done to signal banks that over-investment using depositors' money in risk-less securities whilst ignoring the private sector would give them less on their left-over funds (Aazim, 2013).

\section{Basel Accord II Implementation in Pakistan}

Keeping the importance and challenges in view, SBP guided CBs into devising basic infrastructure for the execution of the Pillars. This operation was based on BSD Circular No. 3 , wherein the roadmap for the process was provided to the banks and Development Finance Institutions (DFI's) (SBP 2005). Consistent with the Pillar-3, SBP revised the existing reporting format/template to include extensive disclosures in BSD Circular No. 04 of 2006 (SBP, 2006). This reporting format has constantly been adapted to the reforms in the Accords. With the adoption of Basel-III in 2013, the format has been revised to include its latest capital requirements disclosures in the annual reports, as per BPRD Circular No. 11 (SBP, 2014). However, the annual reports of 2013 disclosed capital requirements as per the instructions given in BPRD Circular No. 06 (SBP, 2013). Whereas a survey on the implementation of Basel-II in Pakistan, revealed that private CBs are more responsive to Basel-II than public CBs (Masood \& Fry, 2012). This puts into question the supervisory authority of SBP.

There have been several studies on the relationship of disclosures and risk. Nonetheless, literature is largely silent on the effect of Basel-II Pillar-3 regulations. This study aims at filling this gap and carry on the works of previous researchers (Agoraki et al., 2011; Baumann \& Nier, 2004; Bourgain, Pieretti, \& Zanaj, 2012; Demirgüç-Kunt et al., 2008; Jeitschko \& Jeung, 2005; Linsley \& Crumpton, 2006; Linsley \& Shrives, 2005; Östberg, 2006). We empirically examine the relationship of risk disclosures, as under the Basel-II Pillar-3 requirements, with the risk-taking behavior of Pakistani CBs.

\section{METHODOLOGY}

\section{Sampling and Data Collection}

Since this study aims at analyzing commercial bank's risk-takings behavior, the commercial banking sector of Pakistan constitutes the population. As local and foreign banks reside on the opposite extremes because of the differences in policy implementation dynamics and ownership structures; public and private banks are taken into the study. Hence the whole population constitutes the sample used, whereas sample time horizon of 2006-2013 is selected for panel data analysis. Appendix B provides the list of sampled banks.

\begin{tabular}{llll}
\hline JISR-MSSE & Volume 15 & Number 2 & July-Dec 2017 \\
\hline
\end{tabular}




\section{Econometric Model and Statistical Tools}

Ordinary least-squares (OLS) are used for econometric equation estimation. This method is expected to provide the best possible coefficient values along with the appropriate significance levels if the model used is a Single-Equation Linear Model (Wooldridge, 2002, p. 49). This is also consistent with the works of Baumann and Nier (2004).

To incorporate inter-temporal dynamics and the individuality of the entities being investigated panel OLS is the most effective tool (Wooldridge, 2002, p. 251). Since each bank has its own properties and each year has its own seasonal and temporal effects, Panel data OLS analysis is utilized to yield the most efficient results. Whereas Haussmann-Specification test is used to validate the significance of fixed-effects estimator over random-effects estimator. To confirm the presence of fixed cross-sectional effects and period effects in the data, redundant fixed-effects likelihood ratio is utilized. Robust standard errors are used to cater for serial-correlation and hetroskedasticity, as per White (1980).

The econometric model for this study is:

$$
R_{I S K_{i T}}=\beta_{0 i t}+\beta_{1} R D I_{i T}+\beta_{2} S I Z E_{i T}+\beta_{3} R O A_{i T}+\beta_{4} C A P_{i T}+u_{i T} .
$$

Where: RISKiT = risk-weighted-assets to total assets; RDIiT = Risk disclosure index score; SIZEiT $=$ natural-log of total assets; ROAiT = return-on-assets; CAPiT = capital-to-total assets; for bank $\mathrm{i}$ in year $\mathrm{T}$.

Robustness is tested by taking alternate definitions of risk-taking behavior and through sample division. These robustness checks are discussed in the Results section.

\section{Measurement of the Variables}

\section{Risk-Taking Behavior - RISK}

To measure banks' risk-taking behavior (RISK), this study employs the ratio of risk-weighted assets (RWA) to total assets of a bank, consistent with the literature examining portfolio risks in banks (Jacques \& Nigro, 1997; Rime, 2001; Shrieves \& Dahl, 1992). These studies investigated into different aspects of risk-taking behavior and utilized this indicator for portraying the portfolio risk.

Since the ratio of RWA-to-total assets represents a bank's decision process regarding risk-takings along the lines of timeliness, this proxy well defines the variable (Rime, 2001). It is employed while assuming that risk-weights employed by the sample banks align with the economic risk each asset category undertakes (Shim, 2013).

The numeric expression for Risk-taking behavior is:

$$
\text { RISK }_{i T}=\frac{\text { Risk Weighted Assets }}{i T}
$$

For bank $\mathrm{i}$ in year T, RISK is ratio of its risk-weighted assets to its total assets in year T. 


\section{Construction of Risk Disclosure Index - RDI}

The study employed a content analysis technique and construction of an index for disclosures, to compare objectively the content of CBs' annual reports with the requirements of disclosures spelt out in the Basel Accord II Pillar-3.

Throughout literature on the disclosures, self-constructed indices are repeatedly utilized to cater the special and unique needs of disclosure measurement (Baumann \& Nier, 2004; Cooke, 1989; Pérignon \& Smith, 2010). These self-constructed indices are deemed valid despite the nature of the unit of analysis or assortment of information studied (Urquiza, Navarro, \& Trombetta, 2009; Urquiza et al., 2010).

As yet, two methods have been widely utilized for constructing disclosure indices needed for content analyses; the first method uses weights and therefore becomes subjective (Urquiza et al., 2009). The other method requires no such weights and objectively analyzes the presences of a particular item in the content (Urquiza et al., 2010). As long as the focus of the disclosure research is not one particular user group but all the users, giving weights will not render viable results (Cooke, 1989). Attaching weights becomes irrelevant, as firms that can disclose important information would also be better at disclosing not so important items (Spero, 1979).

Therefore, an un-weighted disclosure index is used in this study that is constructed following the methodology of Nier and Baumann (2006). Their index items are replaced by the items on the survey designed by BCBS (2003). This survey was conducted to quantify the implementation of Basel-II Pillar-3 in the member countries. The components of the survey were later technically analyzed by Linsley and Shrives (2005).

The index used in this study comes from the six categories of the BIS survey, namely; Capital Structure, Capital adequacy, Credit risk-modelling, Operational risk, Market risk internal-modelling and other risks. These categories entail disclosure requirement of qualitative and quantitative nature and both. They belong to the basic risk disclosure requirements that are ought to be fulfilled by developed and developing countries alike (Balin, 2008; Linsley \& Shrives, 2005).

The resulting 48 items construct the sub-indices ( $\mathrm{s} \neg \mathrm{d}$ ) following the methodology of Baumann and Nier (2004), aggregate of these sub-indices gives a composite risk disclosure index for a bank. Hence, the index becomes:

$$
R D I=\frac{1}{48} \sum_{d=1}^{48} s_{d}
$$

A sample bank can attain the maximum score of 48. Appendix A provides the items of the sub-indices. The scoring follows nominal method, with a dichotomous scale; that is 1 for disclosure and 0 otherwise (BCBS, 2003). 


\section{Bank Specific Controls}

Different bank specific controls are utilized to cater for the individual properties of banks that can act as determinants of their risk-taking behavior and to further isolate the effect of risk disclosure. They are size, performance and capital base.

\section{Bank Size - SIZE}

The natural-logarithm of total assets, is used as a measure of bank-size in disclosure and risk based studies (Baumann \& Nier, 2004; Bourgain et al., 2012; Duran \& Lozano-Vivas, 2015; Hakenes \& Schnabel, 2011; Jacques \& Nigro, 1997; Rime, 2001). Hence, natural-logarithm of total asset is utilized in this study. Hence the bank size is:

$$
\operatorname{SIZE}_{i T}=\log \left(\text { Total }_{\text {Assets }}{ }_{i}\right)
$$

For bank $\mathrm{i}$ in year T, SIZE is the natural-log of its total assets in year T.

According to González (2005) "too big to fail" behavior makes it difficult to observe the effect of a bank's size on its risk-taking. Because of their large portfolios, banks have greater access to capital markets to adjust capital shortfalls (Francis \& Osborne, 2012). However due to government's implicit assistance in case of financial distress; moral hazard is likely to occur with the increase in size (Shim, 2013). In contrast, charter-value can restrain moral hazard, forcing large banks to curtail excessive risk-takings and seek diversified risks (Keeley, 1990).

\section{Performance - ROA}

In this study we employed return-on-assets (ROA) following Baumann \& Nier (2004). For calculation, following equation is used:

$$
\operatorname{ROA}_{i T}=\frac{{\text { Profit after } \text { Taxation }_{i} T}^{\text {Total Assets }}{ }_{i}}{\text { Tota }}
$$

For bank $\mathrm{i}$ in year $\mathrm{T}, \mathrm{ROA}$ is the ratio of its returns after taxes to its total assets in year $\mathrm{T}$. The total assets used in the calculation of this proxy are net-of-provisions.

High-risk may cause expected returns to increase due to the risks taken however higher returns curb excessive risk-taking as per Bowman's paradox (Andersen, Denrell, \& Bettis, 2007). The decline in the risk-taking, therefore, can be due to the realized returns and improved performance. Hence;

\section{Capitalization - CAP}

This study employs a ratio of a bank's capital to its total assets. The numerical expression is as follows:

$$
\text { CAP }_{i T}=\frac{\text { Capital }_{i} T}{\text { Total Assets }_{i} T}
$$

For bank $\mathrm{i}$ in year T, CAP is the ratio of its capital (sum of common equity, share premium, and unappropriated profits) to its total assets in year $\mathrm{T}$.

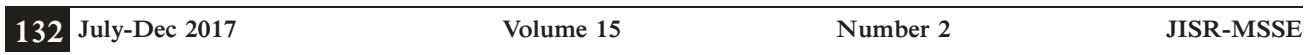


According to Jeitschko and Jeung (2005), a bank's risk tends to decrease with increase in capitalization whenever the shareholder's interest dominates. In the presence of a generous deposit insurance interests of shareholders and managers align. As deposit insurance is yet to arrive in Pakistan (BR Research, 2013), in this scenario shareholder interests are at stake, such that with increased capital the risk incentives decrease ( Jeitschko and Jeung 2005; Duran and Lozano-Vivas 2015; Keeley 1990).

\section{RESULTS \& DISCUSSION}

\section{Risk Disclosure Index Results}

Figure 1 provides the overall disclosure rate for each category covered by the index as listed in Appendix A over the period understudy.

Figure 1: by Item Category

$=2006=2007=2008=2009 \quad 2016-2011=2012=2013$

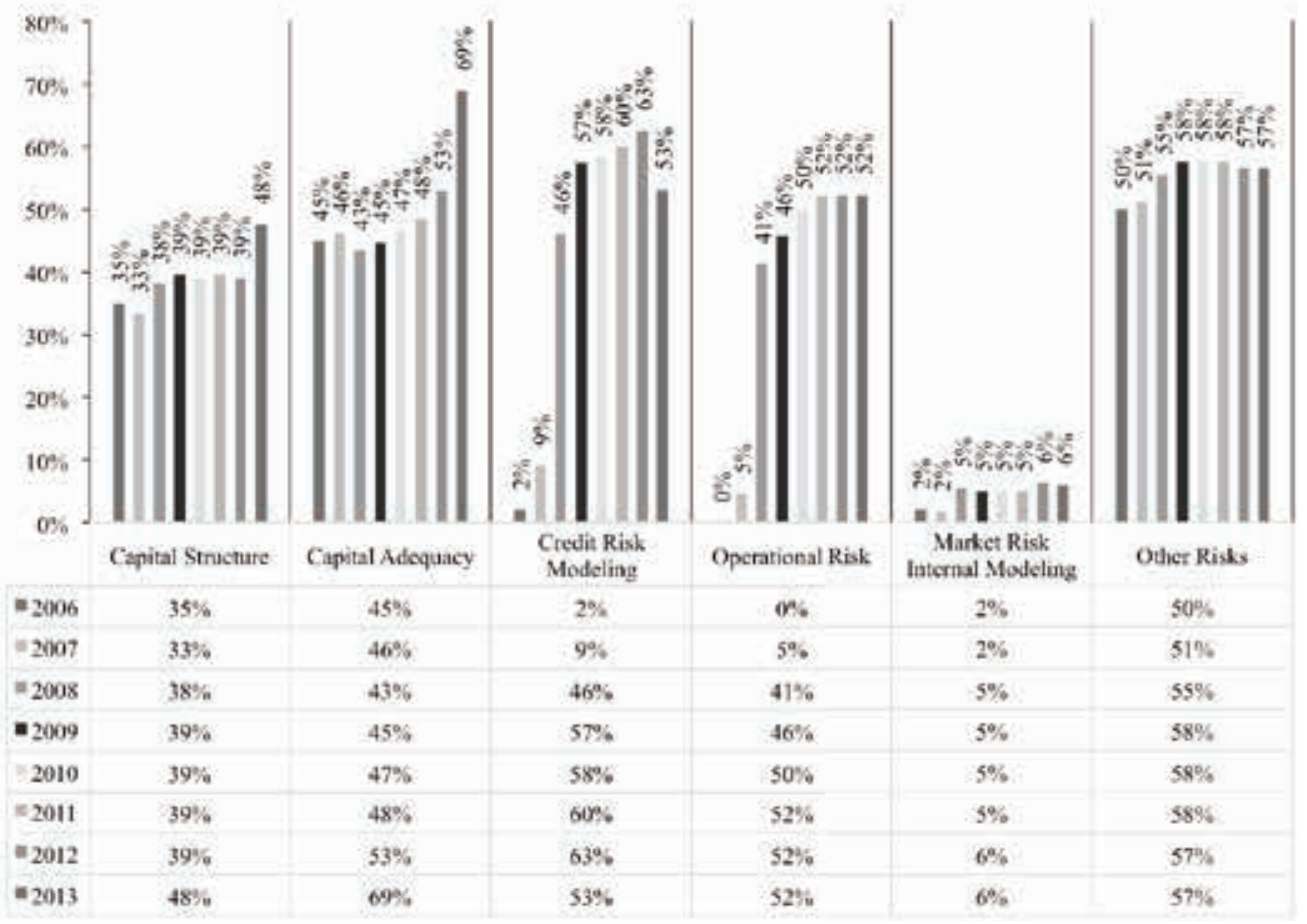

According to Figure 1, the key changes in the overall disclosure rate over the period understudy come from the variations in capital structure and adequacy disclosure outlook. Since these disclosures are considered mandatory for most banks (Linsley \& Shrives, 2005), they are therefore expected to generate relatively high level of disclosures.

However, the disclosure of information on the internal-models for market risk is inadequate with respect to the Pakistani commercial banks. This trend was also apparent in case of standardized approach. This can be due to the differences in the risk-assessment models within 
the sector. Banks also hesitate whilst providing the analysis of changes in the capital structure and the impact thereof. Only a handful of banks provide such analysis, whereas the rest leave it to the stakeholders to analyze and interpret. Since disclosure of such information can lead to penalties under the market discipline; it is deemed fit not to disclose it beforehand (Bischof \& Daske, 2013; Östberg, 2006).

The format designed by SBP to meet minimum requirements of Pillar-3 provides banks with leeway. They follow the format meeting the minimum requirements. However, any auxiliary disclosure made is subjective to their own interests. As disclosure imposes a cost that must be set off with profits, for them to be justified in the first place (Milne, 2002). These results align with that of BCBS (2003) study. However, with the introduction of Basel-III regulations in 2013, the disclosure in each category have improved significantly.

\section{Summary Statistics}

Table 1 provides the summary statistics of all the variables included in the regression estimates as well as in the robustness tests. The data is extracted from the annual reports of 23 banks for 2006-13 with two missing observations, resulting in an unbalanced panel of 182 observations rather than 184.

Table 1: Summary Statistics

\begin{tabular}{llllllll}
\hline Variables & Mean & Max. & Min. & Std. Dev. & Skewness & Kurtosis & J-B Stat \\
\hline RISKiT & 0.624 & 1.032 & 0.294 & 0.141 & 0.261 & 2.919 & 2.133 \\
NPLiT & 0.061 & 0.357 & 0.000 & 0.063 & 2.176 & 8.544 & $378.84 * * *$ \\
Z-scoreiT $\neg$ t & 3.209 & 8.357 & -2.125 & 1.548 & -0.516 & 4.571 & $20.31 * * *$ \\
RDIiT & 0.308 & 0.500 & 0.146 & 0.079 & 0.287 & 2.398 & $5.242 *$ \\
SIZEiT & 18.691 & 21.201 & 15.208 & 1.351 & -0.320 & 2.29 & $6.964 * *$ \\
ROAiT & 0.003 & 0.037 & -0.072 & 0.020 & -1.688 & 6.166 & $163.301 * * *$ \\
CAPiT & 0.107 & 0.533 & 0.003 & 0.084 & 2.442 & 10.062 & $562.211 * * *$ \\
\hline
\end{tabular}

Note. $N=23, T=8$, obs.$=182$

$t N=18, T=8, o b s .=138$

$* p<.1, * * p<.05$, and $* * * p<.01$

Where: RISKiT = risk-weighted assets to total assets; RDIiT = Risk Disclosure index score; SIZEiT $=$ natural-log of total assets; ROAiT $=$ return-on-assets; CAPiT $=$ capital-to-total assets; NPLiT = non-performing loans to total assets; Z-scoreiT = natural-log of the sum of return-on-assets and capital ratio divided by oROA; for bank i in year $\mathrm{T}$.

The data used is extracted from the annual reports of the sample commercial banks.

The normality of the variables was more strictly tested under Jarque-Bera test for normality (Table 1). For RISK series null hypothesis of a normal distribution was accepted, whilst for RDI normal distribution hypothesis was rejected at $10 \%$ significance level but not at 5\%, whereas for SIZE it was rejected at 5\% significance but not at $1 \%$. 
Pearson correlation matrix for the variables given in Table 2, suggested no perfect-collinearity, however indicated a moderate correlation between CAP and SIZE (-60.8\%). This correlation is due to the relationship of size with capital; as small banks need more capital for the fear of liquidation due to their aggressive risk-takings (Francis \& Osborne, 2012; González, 2005). These correlation values established grounds for hypothesis testing, and ruled out the issue of perfect multi-collinearity, and provided bases for further analysis.

Table 2: Pearson Correlation Coefficient Matrix

\begin{tabular}{lllll}
\hline & RDI & SIZE & ROA & CAP \\
\hline RDI & 1 & & & \\
SIZE & 0.436 & 1 & & \\
ROA & 0.220 & 0.450 & 1 & \\
CAP & -0.336 & -0.608 & -0.202 & 1 \\
\hline
\end{tabular}

RDIiT = Risk Disclosure index score; SIZEiT = natural-log of total assets; ROAiT = return-on-assets; CAPiT = capital-to-total assets

\section{Panel-Regression Results and Analysis}

The regression estimations for panel least-squares assumed fixed-effects as suggested by the Haussmann-specification tests whereas two-way fixed-effects were incorporated as per the redundant-fixed-effects-likelihood test results. The results as given in the Table 3 , are estimated by the means of the research equation 1 . Whereas robust-standard error terms are also incorporated to remove hetroskedasticity and serial-correlation from the estimates following White (1980).

Table 3: Regression Estimates using OLS

\begin{tabular}{|c|c|c|c|c|c|c|}
\hline \multicolumn{4}{|c|}{ Unadjusted-standard errors } & \multicolumn{2}{|c|}{ Robust-standard errors } & \multirow[b]{2}{*}{$\mathrm{T}$} \\
\hline Variables & $\beta$ & Std. Err. & $\mathrm{t}$ & $\beta$ & Robust Std. Err. & \\
\hline Intercept & 3.935 & 0.639 & $6.158 * * *$ & 3.978 & 0.900 & $4.42 * * *$ \\
\hline RDI & -0.711 & 0.176 & $-4.042 * * *$ & -0.711 & 0.195 & $-3.64 * * *$ \\
\hline SIZE & -0.165 & 0.033 & $-4.903 * * *$ & -0.165 & 0.047 & $-3.50 * * *$ \\
\hline ROA & 1.231 & 0.465 & $2.648 * * *$ & 1.231 & 0.604 & $3.04 *$ \\
\hline CAP & -0.122 & 0.163 & -0.745 & -0.122 & 0.182 & -0.67 \\
\hline \multicolumn{7}{|c|}{ Model Summary } \\
\hline $\mathrm{R}^{2}$ & & & 0.738 & & & 0.591 \\
\hline Adj. $R^{2}$ & & & 0.677 & & & 0.565 \\
\hline F-stat & & & $12.638 * * *$ & & & $32.200 * * *$ \\
\hline DW-stat & & & 1.53 & & & 1.53 \\
\hline
\end{tabular}

Note. $N=23, T=8$, obs. $=182$,

$t N=18, T=8, o b s .=138$

$* p<.10 . * * p<.05$. *** $p<.01$.

Where: RISKiT = risk-weighted assets to total assets; RDIiT = Risk Disclosure index score; SIZEiT = natural-log of total assets; ROAiT = return-on-assets; CAPiT $=$ capital-to-total assets; for bank i in year $\mathrm{T}$.

\begin{tabular}{llll}
\hline JISR-MSSE & Volume 15 & Number 2 & July-Dec 2017 \\
\hline
\end{tabular}


The regression model assumed an intercept of 3.935 significant at $1 \%$ level. This intercept value can be accredited to the other factors that affect risk taking behavior but were not observed in the present study. The model summary values suggested model fitness at $73.8 \%$ and $67.7 \%$ as depicted by $\mathrm{R} 2$ and adjusted R2 respectively Whereas DW stat showed absence of serial-correlations in the model.

As it is evident from the two-way panel regression estimates (with and without robust-error terms); that the risk-taking behavior responds to the variations in RDI, and selected bank specific controls. Nevertheless, non-significant values recommend that the impact of CAP may be less important than the others with the significant values.

Risk taking behavior has a significant negative relationship with RDI at $1 \%$ significance level. The coefficient value for this indicated $71.1 \%$ increase in the Risk-taking behavior being caused by 1-unit increase in RDI, in the presence of selected bank specific controls.

The regression results establish the significance of transparency in curbing the risk-taking behavior in CBs. Evidently, in Pakistan, market discipline is significantly at play. Transparency achieved through risk disclosures under Pillar-3 is plummeting the risk-takings in the CBs. By punishing excessive risk-taking, increased market discipline is limiting the reasons for moral hazard, consistent with literature on the matter (e.g. Ghosh \& Das, 2005; Duran \& Lozano-Vivas, 2015; Jeitschko \& Jeung, 2005; Baumann \& Nier, 2004; Nier, 2005; Nier \& Baumann, 2006; Martinez Peria \& Schmukler, 2001).

Therefore, $\mathrm{H} 1$ is accepted at $1 \%$ significance level with risk-weighted assets to total assets as a proxy for RISK.

\section{Risk Disclosures and Risk-Taking Behavior of Pakistani Commercial Banks}

The study aims at evaluating the impact of risk disclosures on the risk-taking behavior of Pakistani commercial banks, and to observe market discipline in action. The robust empirical findings establish the significance of transparency in curbing the moral hazard behavior in commercial banks. The regression results are also consistent with findings of Baumann and Nier (2004), who found significant negative impact of disclosures on the risk-taking behavior of commercial banks, in the presence of bank specific controls, in a panel data setting.

Market discipline being the third Pillar of the Basel II intends to establish a market based incentive scheme; wherein investors of banking liabilities (i.e. Depositors) can scrutinize and punish banks by demanding higher yields due to higher risk taking on their funds. Since banks tend to take high risks to earn high profits, doing so leaves them exposed to adverse selection phenomenon (Demirgüç-Kunt et al., 2008; Martinez Peria \& Schmukler, 2001).

Whereas due to relevant risk disclosures, the market participants are able to sanction commercial banks with unsatisfactory risk profile in real time. Looking closely at the summary statistics (Table 1) disciplining mechanism's sensitivity to the disclosure of relevant risk information is observable in the presence of bank specific characteristics. A single unit deviation from the average risk disclosure level is causing twice the opposite deviation in the asset portfolio risk (RWA/TA), and an almost equal opposite variation in the problem loans for Pakistani commercial banks that are well capitalized, profitable and large in size. For

136 July-Dec 2017 Volume $15 \quad$ Number 2


emerging and developing economies such sensitivity is associated with the risk averse depositor base and novice financial markets along with stringent supervisory process (Bourgain et al., 2012).

\section{Risk Disclosures and Risk-Taking Behavior of Pakistani Commercial Banks}

The alternate measures of risk-taking are used to check the robustness and consistency in the estimates. Non-performing loans as a share of total asset are used as an ex-post measure of bank's risk-taking in various studies (e.g. Barth et al. 2004; Beck et al. 2006). Whereas natural-logarithm of Z-scores with a reduced sample size of 18 banks for the period of 2006-13 was employed as an ex-ante measure, following previous researchers (Demirgüç-Kunt et al., 2008; Duran \& Lozano-Vivas, 2015; Laeven \& Levine, 2009; Shim, 2013). As this is an inverse proxy, measuring the distance from bankruptcy; the expected signs change from negative to positive. The results given in Table 4, suggest a significant impact of RDI on the risk-taking in terms of NPLs as well as Z-scores.

Table 4: Robustness Checks

\begin{tabular}{|c|c|c|c|c|c|c|c|c|}
\hline & \multicolumn{2}{|r|}{ NPL } & \multicolumn{2}{|c|}{ Z-Score t } & \multicolumn{2}{|c|}{$\begin{array}{l}\text { Islamic Banks }^{\mathrm{a}} \\
\text { (RISK) }\end{array}$} & \multicolumn{2}{|c|}{$\begin{array}{l}\text { Conventional Banks } \\
\text { (RISK) }\end{array}$} \\
\hline Variable & $\beta$ & $\mathrm{t}$ & $\beta$ & $\mathrm{t}$ & $\beta$ & $\mathrm{t}$ & $\beta$ & $\mathrm{T}$ \\
\hline Intercept & 1.176 & $5.589 * * *$ & 9.380 & 0.922 & 2.936 & $1.980 *$ & 3.247 & $4.405 * * *$ \\
\hline RDI & -0.092 & $-2.419 * *$ & 4.933 & $1.924 *$ & -0.918 & $-2.330 * *$ & -0.541 & $-2.746 * * *$ \\
\hline SIZE & -0.056 & $-5.119 * * *$ & -0.519 & -0.968 & -0.112 & -1.404 & -0.130 & $-3.338 * * *$ \\
\hline ROA & -1.352 & $-4.530 * * *$ & 26.404 & $3.576 * * *$ & 2.583 & $2.562 * *$ & 1.03 & $2.118 * *$ \\
\hline CAP & -0.275 & $-5.197 * * *$ & 21.771 & $4.833 * * *$ & -0.237 & -0.972 & -0.038 & 0.289 \\
\hline \multicolumn{9}{|c|}{ Model Summary } \\
\hline $\mathrm{R} 2$ & & 0.813 & & .656 & & 960 & & 0.718 \\
\hline Adj. R2 & & 0.771 & & .567 & & 925 & & 0.650 \\
\hline F-stat & & $19.436 * * *$ & & $.418 * * *$ & & $.534 * * *$ & & $10.537 * * *$ \\
\hline
\end{tabular}

Note. $N=23, T=8$, obs. $=182$,

$t N=18, T=8, o b s .=138$,

$a N=4, T=8, o b s .=31$

$b N=19, T=8, o b s .=150$

$* p<.10 . * * p<.05$. *** $p<.01$.

Where: RISKiT = risk-weighted assets to total assets; RDIiT = Risk Disclosure index score; SIZEiT = natural-log of total assets; ROAiT = return-on-assets; CAPiT = capital-to-total assets; NPLiT = non-performing loans to total assets; Z-scoreiT $=$ natural-log of the sum of return-on-assets and capital ratio divided by oROA; for bank i in year T.

Evidently, the regulatory stringency is plummeting the problem loans, consistent with the precedent (Barth et al., 2004). The NPLs decrease with the increase in the risk disclosures (Table 4). This change however is small (9.2\%) owing to the not so stringent behavior of SBP. Rather than confiding into market discipline, the regulator is going for other alternatives; like, changes in MDR and repo rates. Such changes are discouraging risk-taking behavior, forcing banks to invest in risk-less securities, whilst crowding out the private sector needs.

\begin{tabular}{llll}
\hline JISR-MSSE & Volume 15 & Number 2 & July-Dec 2017 \\
137
\end{tabular}


Consequently, banks with lower returns have to pay higher interest-rates to attract deposits. Such costs are set off by increasing credit risk ultimately increasing the NPLs (Ghosh \& Das, 2005). As for Pakistani CBs, evidently (Table 4), NPLs significantly increase with the decrease in ROA. Same stands true for Z-scores by assuming a positive sign that increase in performance causes a decrease in risk-taking behavior (and an increase in z-scores), also indicated in the previous researches (Baumann \& Nier, 2004). The capitalization variable also becomes significant with NPLs, this phenomenon of decrease in risk-taking due to decrease in leverage, points to the value-maximizing nature of the banking industry in Pakistan as per the theoretical claims of Keeley (1990).

Islamic Financial Services Board (IFSB) governing Islamic banks also endorses the Basel-II Pillar-3 regulations. On the other hand, SBP does not differentiate between Islamic and conventional when it comes to financial reporting. Thus the impact of risk disclosure should be same for the both. As another robustness check, the sample is split into 4 Islamic and 19 conventional banks to check for consistency and robustness in the results by re-estimating equation 1 for both samples. The results (Table 4) are consistent with those estimated with the whole sample (Table 3), except for size that became insignificant for Islamic banks. However, CAP remained insignificant despite the bifurcation.

Disciplining mechanism's sensitivity to the relevant risk disclosure is observable in the presence of bank-specific characteristics (Table 3 and 4). For emerging and developing economies such sensitivity is associated with the risk-averse depositor base, novice financial markets, and stringent supervisory process (Bourgain et al., 2012).

Since Pakistan falls into either one of the two categories results are fairly relatable; nevertheless, at a conflict with Demirgüç-Kunt et al. (2008); Who argued that low income economies do not increase bank-soundness through adequate information dissemination. If a consensus is drawn among the present findings, Bourgain et al. (2012) and Demirgüç-Kunt et al. (2008) then allegedly Pakistan lies among the emerging economies. Withstanding the inference of Agoraki et al. (2011), the full scale implementation of regulations is evidently capable of ensuring efficient risk-taking behavior in case of Pakistan.

\section{CONCLUSION}

The role market discipline can play in evading financial crisis has come out ever stronger in this endeavor. To minimize adverse choices whilst keeping market equipped with information is not just a dream, but a phenomenon that can help banks manage their risk fronts and keep related-parties content. Conversely, in case of Pakistan SBP does not seem to believe in the power of market discipline. Although there is clear evidence of reduced risk-taking due to increased disclosure, SBP chooses to go for other tools to keep banks' risk profiles in check. Doing so is hindering growth as banks have become too risk-averse, ultimately crowding out private sector. Therefore, a balance should be struck, such that transparency can sustain and private sector growth is not compromised. Since an aggressive decrease in the risk-taking behavior can also hinder the economic growth that is unfavorable for the prosperity of emerging and developing economies alike.

Nevertheless, policy makers and regulators need to keep the risk disclosure requirements intact, and push CBs to make the system resilient in order to correct the risk-taking behavior

\begin{tabular}{|c|c|c|c|}
\hline 138 July-Dec 2017 & Volume 15 & Number 2 & JISR-MSSE \\
\hline
\end{tabular}


of the banks. To assist market discipline, this research gives out the risk disclosure index that can help related-parties in monitoring the transparency on the part of banks with respect to their risk-takings and adverse choices and ultimately sanction banks with excessive risks; ensuring stability in the economy.

\section{REFERENCES}

Aazim, M. (2013, October 7). Floating minimum bank deposit rate. Dawn News, p. 7 October. Karachi. Retrieved from http://www.dawn.com/news/1048037

Agoraki, M. E. K., Delis, M. D., \& Pasiouras, F. (2011). Regulations, competition and bank risk-taking in transition countries. Journal of Financial Stability, 7(1), 38-48. http://doi.org/10.1016/j.jfs.2009.08.002

Akhtar, S. (2007). Pakistan banking sector reforms: Performance and challenges. Karachi, Pakistan: State Bank of Pakistan.

Andersen, T. J., Denrell, J., \& Bettis, R. A. (2007). Strategic responsiveness and Bowman's risk-return paradox. Strategic Management Journal, 28(4), 407-429. http://doi.org/10.1002/smj.596

Balin, B. J. (2008). Basel I, Basel II, and emerging markets: A nontechnical analysis (No. SSRN.1477712). Analysis. Washington DC.

Barakat, A., \& Hussainey, K. (2013). Bank governance, regulation, supervision, and risk reporting: Evidence from operational risk disclosures in European banks. International Review of Financial Analysis, 30, 254-273. http://doi.org/10.1016/j.irfa.2013.07.002

Barako, D. G., Hancock, P., \& Izan, H. Y. (2006). Factors influencing voluntary corporate disclosure by Kenyan companies. Corporate Governance, 14(2), 107-125. http://doi.org/10.1111/j.1467-8683.2006.00491.x

Barth, J. R., Caprio, G., \& Levine, R. (2004). Bank Regulation and Supervision. Journal of Financial Intermediation, 13(2), 205-248.

Basel Committee on Banking Supervision. (2003). Public disclosures by banks: Results of the 2001 disclosure survey. Basel, Switzerland.

Basel Committee on Banking Supervision. (2005). A revised framework on international convergence of capital measurement and capital standards (updated). Basel, Switzerland: Bank for International Settlements.

Baumann, U., \& Nier, E. (2004). Disclosure, volatility, and transparency: An empirical investigation into the value of bank disclosure. FRBNY Economic Policy Review, $10(2), 31-45$.

Beck, T., Demirgüç-Kunt, A., \& Levine, R. (2006). Bank concentration, competition, and crises: First results. Journal of Banking and Finance, 30(December), 1581-1603. http://doi.org/10.1016/j.jbankfin.2005.05.010

Benink, H., \& Wihlborg, C. (2002). The new Basel capital accord: Making it effective with stronger market discipline. European Financial Management, 8(1), 103-115. http://doi.org/10.1111/1468-036X.00178

Besancenot, D., \& Vranceanu, R. (2011). Banks' risk race: A signaling explanation. International Review of Economics \& Finance, 20(4), 784-791. http://doi.org/10.1016/j.iref.2011.02.001

Bessler, W., \& Kurmann, P. (2014). Bank risk factors and changing risk exposures: Capital market evidence before and during the financial crisis. Journal of Financial Stability, 13, 151-166. http://doi.org/10.1016/j.jfs.2014.06.003 
Bischof, J., \& Daske, H. (2013). Mandatory disclosure, voluntary disclosure, and stock market liquidity: Evidence from the EU bank stress tests. Journal of Accounting Research, 51(5), 997-1029. http://doi.org/10.1111/1475-679X.12029

Bourgain, A., Pieretti, P., \& Zanaj, S. (2012). Financial openness, disclosure and bank risk-taking in MENA countries. Emerging Markets Review, 13(3), 283-300. http://doi.org/10.1016/j.ememar.2012.01.002

BR Research. (2013, September 19). Deposit insurance scheme. Business Recorder. Karachi. Retrieved from http://www.brecorder.com

Cooke, T. E. (1989). Disclosure in the Corporate Annual Reports of Swedish Companies. Accounting and Business Research. http://doi.org/10.1080/00014788.1989.9728841

Demirgüç-Kunt, A., Detragiache, E., \& Tressel, T. (2008). Banking on the principles: Compliance with Basel Core Principles and bank soundness. Journal of Financial Intermediation, 17(4), 511-542. http://doi.org/10.1016/j.jfi.2007.10.003

Duran, M. A., \& Lozano-Vivas, A. (2015). Moral hazard and the financial structure of banks. Journal of International Financial Markets, Institutions and Money, 34, 28-40. http://doi.org/10.1016/j.intfin.2014.10.005

Francis, W. B., \& Osborne, M. (2012). Capital requirements and bank behavior in the UK: Are there lessons for international capital standards? Journal of Banking and Finance, 36,803-816. http://doi.org/10.1016/j.jbankfin.2011.09.011

Ghosh, S., \& Das, A. (2005). Market discipline, capital adequacy and bank behaviour. Economic and Political Weekly, 40(12), 1210-1215.

González, F. (2005). Bank regulation and risk-taking incentives: An international comparison of bank risk. Journal of Banking \& Finance, 29(5), 1153-1184. http:/doi.org/10.1016/ j.jbankfin.2004.05.029

Greco, G. (2012). The management's reaction to new mandatory risk disclosure: A longitudinal study on Italian listed companies. Corporate Communications: An International Journal, 17(2), 113-137. http://doi.org/10.1108/13563281211220256

Guttentag, J., \& Herring, R. (1986). Disclosure policy and international banking. Journal of Banking \& Finance, 10(1), 75-97. http://doi.org/10.1016/0378-4266(86)90021-X

Hakenes, H., \& Schnabel, I. (2011). Bank size and risk-taking under Basel II. Journal of Banking \& Finance, 35(6), 1436-1449. http://doi.org/10.1016/j.jbankfin.2010.10.031

Healy, P. M., \& Palepu, K. G. (2001). Information asymmetry, corporate disclosure, and the capital markets: A review of the empirical disclosure literature. Journal of Accounting and Economics, 31(1-3), 405-440. http://doi.org/10.1016/S0165-4101(01)00018-0

Jacques, K., \& Nigro, P. (1997). Risk-based capital, portfolio risk, and bank capital: A simultaneous equations approach. Journal of Economics and Business. http://doi.org/10.1016/S0148-6195(97)00038-6

Jeitschko, T. D., \& Jeung, S. D. (2005). Incentives for risk-taking in banking-A unified approach. Journal of Banking \& Finance, 29(3), 759-777. http://doi.org/10.1016/j. jbankfin.2004.05.028

Jensen, M., \& Meckling, W. (1979). Theory of the firm: Managerial behavior, agency costs, and ownership structure. In Economics Social Institutions (Vol. 1, pp. 163-231). http://doi.org/10.1007/978-94-009-9257-3

Keeley, M. C. (1990). Deposit Insurance, Risk, and Market Power in Banking. The American Economic Review, 80(5), 1183-1200. http://doi.org/10.2307/2006769

KPMG Taseer Hadi \& Co. (2013). Commercial banks operating in Pakistan. Banking Survey 2013. Karachi. Retrieved from www.kpmg.com.pk

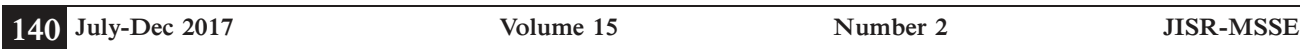


Krugman, P. (2009). The return of depression economics and the crisis of 2008 (1st ed.). New York, NY: W. W. Norton \& Company.

Laeven, L., \& Levine, R. (2009). Bank governance, regulation and risk taking. Journal of Financial Economics, 93(2), 259-275. http://doi.org/10.1016/j.jfineco.2008.09.003

Linsley, P. M., \& Crumpton, M. (2006). Risk disclosure: An exploratory study of UK and Canadian banks. Journal of Banking Regulation, 7(3-4), 268-282. http://doi.org/10.1057/palgrave.jbr.2350032

Linsley, P. M., \& Shrives, P. J. (2005). Transparency and the disclosure of risk information in the banking sector. Journal of Financial Regulation and Compliance, 13(3), 205-254. http://doi.org/10.1108/13581980510622063

Lundholm, R., \& Van Winkle, M. (2006, December). Motives for disclosure and non-disclosure: a framework and review of the evidence. Accounting and Business Research. http://doi.org/10.1080/00014788.2006.9730044

Martinez Peria, M. S., \& Schmukler, S. L. (2001). Do depositors punish banks for bad behavior? Market discipline, deposit insurance, and banking crises. The Journal of Finance, 56(3), 1029-1051. http://doi.org/10.1111/0022-1082.00354

Masood, O., \& Fry, J. (2012). Risk management and Basel-Accord-implementation in Pakistan. Journal of Financial Regulation and Compliance, 20(3), 293-306. http://doi.org/10.1108/13581981211237981

Milne, M. J. (2002). Positive accounting theory, political costs and social disclosure analyses: A critical look. Critical Perspectives on Accounting, 13(3), 369-395. http://doi.org/10.1006/cpac.2001.0509

Nier, E. (2005). Bank stability and transparency. Journal of Financial Stability, 1(3), 342-354. http://doi.org/10.1016/j.jfs.2005.02.007

Nier, E., \& Baumann, U. (2006). Market discipline, disclosure and moral hazard in banking. Journal of Financial Intermediation, 15(3), 332-361. http://doi.org/10.1016/j. jfi.2006.03.001

Östberg, P. (2006). Disclosure, investment and regulation. Journal of Financial Intermediation, 15(3), 285-306. http://doi.org/10.1016/j.jfi.2006.01.002

Pérignon, C., \& Smith, D. R. (2010). The level and quality of Value-at-Risk disclosure by commercial banks. Journal of Banking \& Finance, 34(2), 362-377. http://doi.org/10.1016/j.jbankfin.2009.08.009

Rime, B. (2001). Capital requirements and bank behaviour: Empirical evidence for Switzerland. Journal of Banking and Finance, 25(4), 789-805. http://doi.org/10.1016/S0378-4266(00)00105-9

Saleem, S. (2014, March). The rise and fall of banking spreads. Business Recorder Banking Review 2013, 10-11. Retrieved from www.brecorder.com/br2013

Savvides, S. C. (2012). Market risk disclosures of banks: a cross-country study. International Journal of Organizational Analysis, 20, 379-405. http://doi.org/10.1108/19348831211268599

Scott, W. R. (2014). Financial accounting theory (7 $7^{\text {th }}$ ed.). Toronto, Canada: Pearson Education Canada.

Shim, J. (2013). Bank capital buffer and portfolio risk: The influence of business cycle and revenue diversification. Journal of Banking and Finance, 37(3), 761-772. http://doi.org/10.1016/j.jbankfin.2012.10.002

\begin{tabular}{lllll}
\hline JISR-MSSE & Volume 15 & Number 2 & July-Dec 2017 & 141
\end{tabular}


Shrieves, R. E., \& Dahl, D. (1992). The relationship between risk and capital in commercial banks. Journal of Banking \& Finance, 16(2), 439-457. http://doi.org/10.1016/0378-4266(92)90024-T

Spero, L. L. (1979). The extent and causes of voluntary disclosure of financial information in three European capital markets: an exploratory study (Unpublished Doctoral Dissertation No. Unpublished doctoral dissertation). Harvard University, Cambridge.

State Bank of Pakistan. (2005). Implementation of Basel II in Pakistan (BSD Circular No. 3 of 2005). Karachi, Pakistan: Author.

State Bank of Pakistan. (2006). Revised forms of annual financial statements (BSD Circular No. 04). Karachi, Pakistan: Author.

State Bank of Pakistan. (2013). Implementation of Basel III capital instructions (BPRD circular No. 06). Karachi, Pakistan: Author.

State Bank of Pakistan. (2014). Capital adequacy related disclosure requirements under Basel III implementation (BPRD Circular No. 11). Karachi, Pakistan: Author.

Urquiza, F. B., Navarro, M. C. A., \& Trombetta, M. (2009). Disclosure indices design: Does it make a difference? Revista de Contabilidad, 12(2), 253-277. http://doi.org/10.1016/S1138-4891(09)70008-1

Urquiza, F. B., Navarro, M. C. A., Trombetta, M., \& Lara, J. M. G. (2010). Disclosure theories and disclosure measures. Spanish Journal of Finance and Accounting / Revista Española de Financiación $Y \quad$ Contabilidad, 39(147), $393-420$. http://doi.org/ 10.1080/02102412.2010.10779686

Vauhkonen, J. (2011). The impact of Pillar 3 disclosure requirements on bank safety. Journal of Financial Services Research, 41(1-2), 37-49. http://doi.org/10.1007/s10693-011-0107-x

White, H. (1980). A heteroskedasticity-consistent covariance matrix estimator and a direct test for heteroskedasticity. Econometrica, 48, 817-838. http://doi.org/10.2307/1912934

Wooldridge, J. (2002). Econometric analysis of cross section and panel data. London, United Kingdom: The MIT Press. 


\section{APPENDICES}

\section{Appendix A: Risk Disclosure Check List}

\begin{tabular}{l|l}
\hline$S_{d}$ & Item \\
\hline Capital Structure \\
\hline Qualitative \\
\hline S01 & Disclosed the issuance of capital through SPV \\
\hline S02 & Disclosed key "trigger" events \\
\hline S03 & Disclosed the amount of common-shareholders' equity \\
\hline S04 & Disclosed the total capital base \\
\hline S05 & Disclosed the amount of Tier-one capital \\
\hline S06 & Disclosed the amount of perpetual non-cumulative preference shares \\
\hline S07 & Disclosed the amount of minority interests in the equity of subsidiaries \\
\hline S08 & $\begin{array}{l}\text { Disclosed the amount of innovative or complex capital instruments, including the } \\
\text { percentage of total Tier-one capital }\end{array}$ \\
\hline S09 & Disclosed the amount of Tier-three capital, where applicable \\
\hline S10 & Disclosed deductions from Tier-one and Tier-two capital \\
\hline S11 & $\begin{array}{l}\text { Disclosed the amount of Tier-two capital with separate disclosure of material } \\
\text { components }\end{array}$ \\
\hline Both & $\begin{array}{l}\text { Disclosed the maturity, including call features of complex or hybrid capital } \\
\text { instruments }\end{array}$ \\
\hline S12 & $\begin{array}{l}\text { Disclosed provisions of capital instruments permitting interest of dividend-deferrals } \\
\text { or any other cumulative characteristics, where applicable }\end{array}$ \\
\hline S13 & $\begin{array}{l}\text { Disclosed step-up provisions for capital instruments (where applicable) } \\
\text { Capital Adequacy }\end{array}$ \\
\hline Qualita
\end{tabular}

Qualitative

S15 $\quad$ Disclosed whether the bank has an internal process for assessing capital adequacy and for setting appropriate levels of capital

\begin{tabular}{l|l}
\hline Quantitative \\
\hline S16 & $\begin{array}{l}\text { Disclosed the risk-based capital ratio calculated in accordance with the methodology } \\
\text { prescribed in the Basel Capital Accord }\end{array}$ \\
\hline S17 & $\begin{array}{l}\text { Disclosed the risk exposure of each off-balance sheet instrument (specifying } \\
\text { nominal amount, credit equivalent amount and risk-weighted amount for each risk } \\
\text { bucket) }\end{array}$ \\
\hline S18 & $\begin{array}{l}\text { Disclosed the risk exposure of balance sheet assets (specifying book-value and } \\
\text { risk-weighted amount for each bucket) }\end{array}$ \\
\hline Both & $\begin{array}{l}\text { Provided analysis of changes in the bank's capital structure and the impact on key } \\
\text { ratios and overall capital position }\end{array}$ \\
\hline
\end{tabular}

\begin{tabular}{llll}
\hline JISR-MSSE & Volume 15 & Number 2 & July-Dec 2017 \\
1433
\end{tabular}




\begin{tabular}{|c|c|}
\hline S20 & $\begin{array}{l}\text { Provided all information relevant to understanding how Basel Capital Accord } \\
\text { requirements for market risk under the internal models approach have been } \\
\text { calculated. }\end{array}$ \\
\hline $\mathrm{S} 21$ & $\begin{array}{l}\text { Disclosed all information relevant to understanding how Basel Capital Accord } \\
\text { requirements for market risk under the standardized approach have been calculated, } \\
\text { including disclosure of capital charges for component risk elements, as appropriate. } \\
\text { Credit Risk Modeling }\end{array}$ \\
\hline \multicolumn{2}{|r|}{ Qualitative } \\
\hline S22 & $\begin{array}{l}\text { Disclosed whether credit risk measurement models are used, if so, provided } \\
\text { descriptive information about the types of models, portfolio(s) covered and their size }\end{array}$ \\
\hline $\mathrm{S} 23$ & $\begin{array}{l}\text { Disclosed how the bank has incorporated historical default experience for different } \\
\text { asset categories, current conditions, changes in portfolio composition and trends in } \\
\text { delinquencies and recoveries }\end{array}$ \\
\hline $\mathrm{S} 24$ & $\begin{array}{l}\text { Disclosed whether credit-scoring is used when granting credit, and if so, provided } \\
\text { descriptive information about the credit scoring model and how it is used }\end{array}$ \\
\hline $\mathrm{S} 25$ & $\begin{array}{l}\text { If an institution stress tests its counterparty credit exposures, it should disclose its } \\
\text { process for stress testing, and how testing is incorporated into its risk management } \\
\text { system }\end{array}$ \\
\hline \multicolumn{2}{|r|}{ J } \\
\hline S26 & $\begin{array}{l}\text { Disclosed quantitative and qualitative information about the credit risk measurement } \\
\text { models used, including model parameters (e.g. holding period, observation period, } \\
\text { confidence interval), performance over time, and model validation and stress testing } \\
\text { Operational Risk }\end{array}$ \\
\hline \multicolumn{2}{|r|}{ Qualitative } \\
\hline S27 & $\begin{array}{l}\text { Disclosed the approach (es) for operational risk capital assessment for which the } \\
\text { bank qualifies. }\end{array}$ \\
\hline $\mathrm{S} 28$ & $\begin{array}{l}\text { Disclosed information about the main types of operational risk and identified and } \\
\text { discussed specific issues considered to be significant }\end{array}$ \\
\hline \multicolumn{2}{|r|}{ Market Risk Internal Modeling } \\
\hline \multicolumn{2}{|r|}{ Qualitative } \\
\hline S29 & Disclosed the type of internal models used (e.g. historical simulation, VaR) \\
\hline S30 & Described the portfolios covered by the bank's internal model \\
\hline S31 & Provided an overview of policies and procedures for stress testing internal models \\
\hline S32 & Provided an overview of policies and procedures for back testing internal models \\
\hline \multicolumn{2}{|c|}{ Quantitative } \\
\hline S33 & $\begin{array}{l}\text { Provided summary quantitative information on market risk exposure based on } \\
\text { internal methods used for measurement, with information on performance in } \\
\text { managing those risks }\end{array}$ \\
\hline S34 & For those disclosing VaR data, provided high/low VaR \\
\hline S35 & For those disclosing VaR data, provided average VaR \\
\hline 144 & JISR-MSSE \\
\hline
\end{tabular}




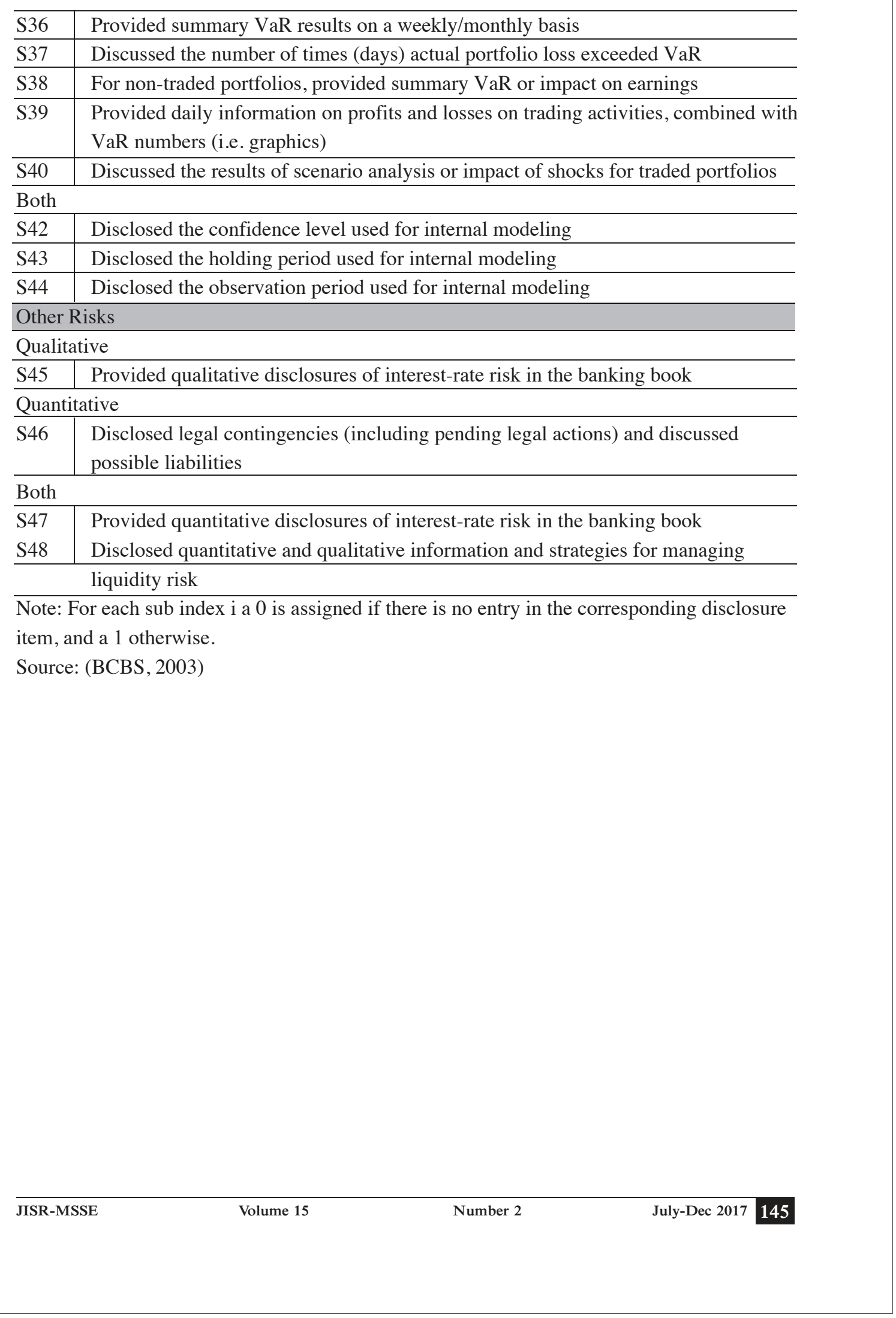




\section{Appendix B: Sample Banks}

Sample Banks

\begin{tabular}{llll}
\hline Sr. & Commercial Banks & Sr. & Commercial Banks \\
\hline 1. & Allied Bank Ltd. & 13 & Meezan Bank Ltd. \\
2. & Askari Bank Ltd. & 14. & National Bank of Pakistan \\
3. & Bank Alfalah Ltd. & 15. & NIB Ltd. \\
4. & Bank Al-Habib Ltd. & 16. & Soneri Bank Ltd. \\
5. $\quad$ Bank of Khyber Ltd. & 17. & United Bank Ltd. \\
6. $\quad$ Bank of Punjab Ltd. & 18. & Silk bank Limited \\
7. & Faysal Bank Ltd. & 19. & Samba Bank Ltd. \\
8. & First Women Bank Ltd. & 20. & Habib Metropolitan Bank Ltd. \\
9. $\quad$ Habib Bank Ltd. & 21. & Bank Islami Ltd. \\
10. KASB Bank Ltd. & 22. & Burj Bank Ltd. \\
11. & MCB Ltd. & 23. & Dubai Islamic Bank Pakistan Ltd. \\
12. & JS Bank Ltd. & & \\
\hline
\end{tabular}

